\title{
Public Access to Local Records*
}

\author{
by Frank D. Gatton \\ Division of Archives and History \\ North Carolina Department of \\ Cultural Resources
}

The history of the local records of neglect. In fully one-third of the counNorth Carolina is a story of destruc- ties, the losses have been serious intion, loss, and neglect. In at least deed. Fires have consumed sixty-six of our counties, records have numerous county courthouses, been lost to fire, water, military opera- destroying priceless records. To note tions, vermin, high temperatures and only a few such disasters, humidity, theft, improper custody, or

- Paper presented in Chapel Hill at the ninth Library TrusteeLibrarian Conference, March 23, 1976. courthouses in Anson (1868), Bladen (1800, 1893), Buncombe $(1830,1835$, 1865), Clay (1870), Greene (1876), 
Harnett (1792, 1894), Hertford (1832, 1862), Iredell (1854), Lenoir (1878, $1880)$, Moore (1833, 1889), Onslow (1752, 1786), Pitt $(1858,1910)$, and Watauga (1873) have been destroyed.

In addition, military operations have taken a heavy toll on local records. During the Revolution, for example, some records were removed from a courthouse and buried in an effort to prevent their capture by enemy forces. The resurrection of those records may have come too late for their survival. During the Civil War, courthouses were burned and records were destroyed in several counties. The courthouses of Burke and Hertford counties were allegedly destroyed by federal troops.

Furthermore, official neglect has taken its toll in both the quality and quantity of records now available to us. In fact, the Regulator Movement was directed against the abuses of local officials in the performance of their duties. The failure of officials to preserve records has deprived all future generations of much desired information. Too, overzealous housecleaning by officials of supposedly worthless records has made it difficult to find certain types of information in some counties. I hasten to add, however, that the majority of the local officials did a very good job and, because they did, a very large quantity of our early records is still available today.

Just about the time more substantial courthouses were being built to protect the records better, a new peril to records arose. This was the simple lack of space to house the ever- increasing quantity of records. Valuable records no longer needed in the operation of county government were removed from the safety of vaults to other areas of the courthouse or to ill-equipped storage buildings. Sometimes they were destroyed outright. In one case, records no longer referred to regularly were moved from a crowded vault to an unused upstairs room of the courthouse. In the 1930s, this particular room was suddenly needed for office space. The "dirty mess" which

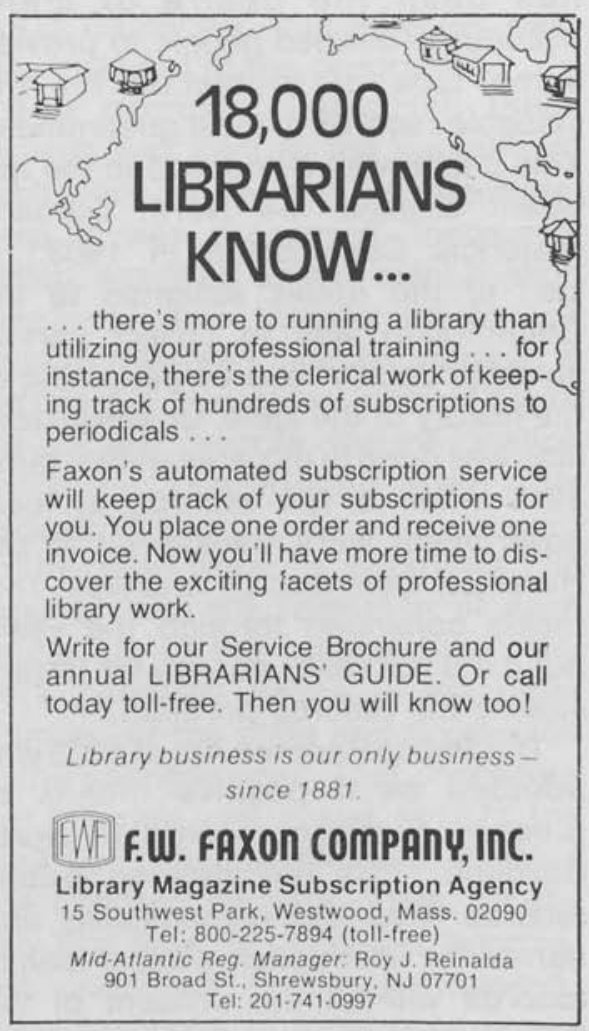


was in the room was removed by the janitor and consigned to the city dump. In another county, a similar situation prevailed. The records were removed from the vault to a room in the courthouse. When additional office space was needed, they were transferred to a county building some distance away. As time passed on, these records were simply forgotten and they were not discovered until this past year. Hopefully, they will soon be back in the official custody of the office responsible for them.

Because of the loss of so many records down through the years, it has been the desire of many historically-minded people to provide some type of protection for the valuable records of local government. This desire was evidenced in the law which created the North Carolina Historical Commission in 1903. ${ }^{1}$ A part of the duties assigned to the Commission was to collect certain valuable county records pertaining to the history of the state. Unfortunately, little was done in this area until around 1916 when a few records of local government were transferred to the Historical Commission Archives. This trickle continued through the years but it did not really go very far toward solving the records problem.

The Public Records Act of 1935 was adopted as a positive means of preserving public records in North Carolina. This law defined public records, fixed legal responsibility, and barred the destruction, sale, or loan of records without the consent of the Commission. It also required officials to deliver records to successors at the end of their term; to demand custody of records from anyone in illegal possession of them and to make records available for use. Finally, it urged the repair of deteriorated records and the storage of all records in fireproof vaults and pledged the Commission's assistance to officials in their records work. This act, as amended, is our current basic public records law.

In 1941, the Genealogical Society of the Church of Jesus Christ of LatterDay Saints, in cooperation with the Historical Commission, began a program to microfilm many of the records of the state's older counties. This program had advantages for all concerned. The Society, of course, secured copies of the records for their use. The Commission (which soon became the State Department of Archives and History) was given a copy of the microfilm for public use, and the county officials could rest a little easier knowing that a portion of their records was enjoying greater security than ever before.

Concern for the remaining vast accumulation, however, continued to be a problem for department officials. Various committees met through the years to assist in determining which records should be kept and which could be destroyed. Their work brought temporary relief to several counties, but this, too, did not solve the basic problem.

In the latter half of the 1950s, hard work and favorable circumstances fostered the creation of a program for the protection of these records. Dr. Christopher Crittenden had worked 
for many years for a solution to the various problems surrounding local records. When Dr. H.G. Jones was appointed to the position of State Archivist, Dr. Crittenden found a man who was equally interested in the situation. Dr. Jones immediately went to work and soon formulated the basic features of the program. He was very fortunate to secure the services of Rear Admiral A.M. Patterson (U.S. Navy, Retired) in developing and heading the operation of this program. With these three "giants" of the department working on the project, great things were both anticipated and effected. As a result of their labor the 1959 legislature created the local records program, which has successfully provided protection for the priceless records of local government in courthouses throughout the state and has served as the model for similar programs in several other states.

What exactly is the local records program? It has been defined as a program of assistance to county, municipal, and other local government agencies in all matters relating to the creation, maintenance, preservation, and disposal of public records. The program includes inventorying and scheduling records for retention in the county offices or in the State Archives, or for ultimate disposal; repairing as necessary and microfilming for security permanently valuable records; storing and servicing microfilm negatives; assisting local government officials in establishing new systems of recording, filing, and making available the records in their custody; assisting in the selection of equipment, paper, ink, and the like; and giving advice and assistance in all areas of their records management activities.

The program began in $1959 \mathrm{im}-$ mediately after the passage of the legislation authorizing the department to begin security microfilm operations in the county courthouses throughout the state. Those records deemed to have permanent or enduring value were selected for microfilming. They included such records as court minutes, deeds, estates records, vital statistics, and wills. The minutes of North Carolina's municipalities were also included in the program.

The microfilm containing these records was sent to the department each week by the camera operators. Here it was processed, inspected, edited, assigned unique identification numbers, and transferred to the security microfilm vault for storage. In the event of the untimely loss of any of the original records, the information could be reproduced from this security film.

The plan was to microfilm the records from the formation of each county up to the present time. The work generally began in the older counties of the state and proceeded to the younger ones. That procedure was followed until, at last, in 1971, the work had been completed in all of the one hundred counties. Thus, for the very first time, the priceless information contained in the permanently valuable books of local government for this segment of time had been preserved on microfilm. Immediately 
upon the completion of this phase of the work a second phase began. Workers returned to each county and microfilmed those records of permanent value which had been created since the previous visit. This is a continuing program.

An important fringe benefit of the program concerns microfilm copies of those records from each county which were deemed especially useful for historical and genealogical research have been made available for public use in the State Archives. Now an individual researcher can examine every county's records on one microfilm reader. Presently there are over 22,000 reels of microfilm containing county records, and many reels containing minutes of North Carolina's municipalities, which are available for public use.

In addition to microfilming, the program provided for another important activity. This was the transfer to the Archives for permanent preservation records which were no longer required for administrative use in the offices of origin, but which contained information of continuing historical and reference value. These were the records which were so rich in informational value but which were, in many instances, in peril of being destroyed. In too many cases, these records had been stored in hot attics or damp basements, or had been banished to unprotected warehouses or storerooms where they were all too soon forgotten and left to the ravages of time. Included among these records were various bonds, court minutes, copied deed and will books, estates records, marriage records, and tax records.

Most such records dating prior to 1900 have now been transferred to the department where they have been appraised, arranged, and described; are currently being worked; or are scheduled to be processed at some future time. The collection totals several thousand volumes and many thousands of cubic feet of unbound records. The vast majority of these records are available to the researcher in the State Archives.

In recent years, research into local records has increased significantly and, from all appearances it will increase even more rapidly in future years. To help meet the growing demands, and to provide materials for local history classes, the Department (now the Department of Cultural Resources) entered into an agreement with the Division of Community Colleges to provide a core collection of microfilm to the community colleges and technical institute libraries throughout the state. The "core" consists of records of considerable research value which were created by county offices from the formation of the county until around 1870. Each institution that participated in the project ordered film for the county in which it was located and for its parent county or counties. In some instances, the core collections for neighboring counties were purchased if the institution represented them as well. This film is available for use by the citizens of the area and has been especially beneficial to the students in the local history and biography classes taught 
at those institutions. One further provision of this arrangement is to require the institutions to establish an inter-library loan arrangement on all microfilm received under the core agreement. This means that patrons of Mitchell Community College in Statesville, for example, may request the loan of a reel of microfilm held in the library of Asheville-Buncombe Technical Institute, or from any other institution in the community college system.

In a further attempt to make the local records of greatest use in historical and genealogical research readily available to researchers throughout the state - and throughout the nation - an agreement was made with the State Library which fully utilized its excellence in inter-library loan service. A complete core collection - about 3,500 reels of microfilm - was provided at special cost to the Genealogy Branch of the library, which lends microfilm as readily as any book in the collection to any other library in the state or in the United States.

This arrangment makes a sizeable portion of the more important records of local government fully available for historical and genealogical research. We believe that this concept will prove to be of such great benefit that it will set the trend for the profession in the future.

Many public libraries have also taken advantage of the opportunity to obtain core collection microfilm pertaining to their county or area. They, of course, will not be as dependent as others upon inter-library loan provi- sions, but they too can supplement their holdings easily by using it.

To summarize, the local records of North Carolina are available to the public in numerous ways. Of course, many records of local governments are retained in the local offices and are available there. Included among these are records of deeds, records of wills, commissioners' minutes, armed forces discharges, and marraige registers. By virtue of the local records program, these records and numerous others deemed to have permanent value have been microfilmed for security and copies of the film are available to the public in the State Archives. In addition, very large quantities of original records dating prior to 1900 , both bound and unbound, from most of the counties are available for public use in the State Archives.

Microfilm copies of many records are available to the public at the community college and technical institute libraries throughout the state. For those who prefer public libraries, microfilm containing records of almost every county in the state is available either in the libraries or is available to the libraries on an interlibrary loan basis from the Genealogy Branch of the State Library.

All that is needed now is just the time to use these resources.

\section{Footnotes}

'A fuller account of the early efforts to preserve North Carolina public records may be found in H.G. Jones, For History's Sake: The Presentation and Publication of North Carolina History, 1663-1903 (Chapel Hill: University of North Carolina Press, 1966). 